\title{
Marxist Propagation Path and Contemporary Enlightenment in Guizhou Minority Areas during the Long March
}

\author{
Qiang Zhang ${ }^{1}$, Xueyan Wang ${ }^{2}$ \\ ${ }^{1}$ Sichuan Agricultural University, Sichuan, Yaan, China, 625014 \\ ${ }^{2}$ Sichuan Water Conservancy Vocational College, Sichuan, Chengdu, 611231
}

Keywords: The Long March, the Popularization of Marxism, the Minority Areas, the Path Selection

\begin{abstract}
Red Army Long March are mostly ethnic areas in Guizhou during the activities of the region, where the socio-economic backwardness, ethnic relations are complex, Miao and Han serious opposition. The Red Army must pass through these ethnic areas, it must spread the Marxist theory, propaganda of the party and the Red Army's nature, principles, routes, policies, to solve the tense national relations. During the period of Guizhou, the Red Army opened up a new path of Marxism popularization, which changed the attitude of the people to Marxism. From the exclusion to the understanding, acceptance, recognition and belief, the Red Army gained the support and support of the minority, the smooth realization of the strategic shift. To learn from history, the Red Army in Guizhou during the promotion of Marxist popular work experience is worth learning, its contemporary value is rich.
\end{abstract}

\section{The Significance of the Spread of Marxism in Guizhou Minority Areas during the Long March}

The Long March of the Chinese Workers 'and Peasants' Red Army Long March is a strategic shift of large-scale personnel and materials, of which Guizhou is one of the provinces with the longest and most prosperous in the 11 provinces that the Central Red Army crossed during the Long March. The Central Red Army in Guizhou for four months, here in a series of time and space nodes on the occurrence of some major events, such as monkey meeting, Zunyi meeting, cock crow three meetings and a series of meetings, the formation of the Central Red Army Long March The most important part of the historical link, but also to save the party, the Red Army and the Chinese revolution in the historical turning point. In the Chinese revolutionary crisis, Guizhou became the Red Army recuperate, grow and develop an important place, cannot but say that Guizhou is the Chinese revolution "blessed land." During the period of the Long March in Guizhou, the activities area of the Long March in Guizhou was mostly ethnic areas, mainly Miao, Yao, Zhuang, Dong, Tujia, water, white, Li, Qiang, Bu Yi, Gelao, Naxi and other ethnic minority areas or mixed areas. Historically, the peoples of the various generations of generations in the canyon deep gully reclamation, hard to survive, but they created the wealth was the ancient soil officials, flow officials to rent and apportionment and other forms of large swept away. Since the Republic of China, due to the reaction of the Kuomintang reactionary government and the oppression of local warlords, so the ethnic minorities and Han have a deeper gap. On the way to the long march, the Red Army must pass through these ethnic areas, it must propagate the party and the Red Army's nature, principles, routes, policies, spread the Marxist theory, so as to bridge the gap between the nation, to eliminate the misunderstanding of the party and the Red Army, support Chinese revolutionary cause. 


\section{The Path Choice of Marxist Communication in Guizhou Minority Areas during the Long March}

\subsection{Innovative Ways of Propaganda, So the Masses Close to Marxism in the Understanding}

During the Long March, the Red Army away from the base, the lack of a stable logistical support, and the place after the more remote and backward, coupled with the enemy's confuse propaganda, so that the majority of the masses of the Red Army's image there are various prejudices, so the Red Army propaganda work Is particularly important. In response to this situation, the Red Army attaches great importance to educating the masses through propaganda. First, play the main role of the press. The Red Army authorities reported on the long march to publish timely convey the party's line, principles, policies and the Red Army's fighting command. "Red Star" newspaper, "warrior" newspaper, "health newspaper", "red furnace", "red bucket supplement", "forward" and other newspapers issued propaganda agitation, greatly encouraged the Red Army officers and men of revolutionary fighting spirit, unity education along the way the broad masses of the people, the collapse of the enemy morale, the Long March victory played an important role. Secondly, publicity slogans and posters are the main means of publicity. Where does the Red Army go? Propaganda cartoon drawn in the urban and rural areas along the way, vivid, profound meaning, and some exposed the reactionary rule of the Kuomintang, and some reflect the workers and peasants to participate in the Red Army, the Red Army led the masses to fight ho and so on. Again, in the form of revolutionary poetry and revolutionary songs express the confidence of the revolution and pride aspirations. In the Long March, the revolutionary song has a wide range of forms, flexible and diverse, aggressive and fighting. The Red Army, through singing revolutionary songs, carried out political mobilization and revolutionary propaganda, held singing competitions, active cultural life of the Red Army soldiers, and carried out ideological and political education. Where the Red Army went, posting the propaganda, propagating the purpose of the Red Army and protecting the workers and peasants 'claims; calling on the masses to overthrow the rule of the warlord bureaucracy, create the workers' own power and seek their own liberation and freedom. Speaking is a face-to-face communication, propaganda of the party's policy is easier to clarify the facts and express emotions, the propaganda of Marxism are better. In Zunyi city, many students took to the streets to speak, and many comrades in the past had suffered the Kuomintang warlords landlord gentry brutal exploitation and oppression, they can use their own personal experience to explain the revolutionary truth to the masses, more Has an appeal. The Red Army used a variety of propaganda of the party's line, principles and policies spread the Marxist theory, so that the national masses to recognize the Chinese Communist Party, understand the Chinese revolution, eliminate the gap, narrow the distance, resulting in a sense of intimacy.

\subsection{Implement the Party's Mass Line, so that the Masses in Close to Accept Marxism}

As a result of the rumors of the Kuomintang, the people along the way did not understand the Red Army, the arrival of the Red Army with fear and alertness, resulting in the early arrival of the Red Army in Guizhou ethnic areas suffered great difficulties. Township people fled to the countryside, the people of the village and fled to the mountains, hiding in the caves, food, livestock and other solid wall, so as not to fall into the hands of the Red Army, which gave the Red Army caused great difficulties. The existence of such hostile sentiments is far less of the spread of Marxism to them. In order to appease the local people, to eliminate their doubts and alert mentality, the Red Army to effectively protect the interests of all ethnic groups, the strict implementation of the three disciplines of eight doctrine, public buy, March 1935, the Red Army had Renhuai, a Red Army soldiers to hide the enemy machine, in the Gelao people to choose a stone next to a stone found a small tank of lard and a few pieces of copper, busy to give them Business election was only very busy, busy to call out to hide the Red Army and hidden in the woods of the two daughters, to the Red Army cooking water for the Red Army to fight sandals, the Red Army to go when the business before they reluctantly, insisted When the wizard. On the road, a Red Army soldier put a red carpet on his shoulders, let him rain. After the Red Army, he has been treasured this piece of red 
felt, after the people close to each other wedding festivals, have to borrow this piece of red carpet shop to add festivity. In Taizhou County, Guizhou Miao village, the Red Army left, the Miao poor elderly Zhang Laoqiao in the pig food basin found the Red Army left forty silver dollars to buy pig money. The Red Army officers and men to their own practical action, exposing the Kuomintang in the minority areas scattered Red Army to "kill the fire", "extinction of ethnic minorities" deceit propaganda, so that ethnic minorities really see who is their enemy, who is their Of the savior, the attitude of the Red Army from fear, doubt, alienation into trust, close and support, and thus completely shattered the Kuomintang reactionaries want the Red Army to death, freeze to death, starvation in ethnic minority areas of the attempt.

\subsection{Implement the Party's National Policy, So that the Masses in the Acceptance of Marxism}

During the Long March of the Red Army in the Long March, the main route through the Miao, Yao, Dong, cloth, such as Qiandongnan, northeast of the ethnic minority areas and mixed areas. These areas have always been complex ethnic relations, so how to formulate corresponding national policies according to the different national characteristics of the locality, correctly handle ethnic issues, coordinate ethnic relations, earnestly propagate and carry out the Party's national policies, and expose the Kuomintang to the Communist Party and the Red Army Rumors and slanders, dealing with conflicts and conflicts with ethnic minorities, became the party and the Red Army was facing an urgent problem to be solved. In order to promote the party's national policy and let ethnic minorities understand, understand, sympathize with and support the Red Army, the Chinese Communist Party upholds the principle of national equality, opposes national oppression and ethnic discrimination, and puts forward a series of policies such as respect for religious freedom, the establishment of minority nationalities and the development of national economic and cultural policies, and in practice to be implemented. In addition, a series of instructions, resolutions and bulletins on ethnic issues have been issued, and a policy and proposition about ethnic minorities has been clearly presented. December 24, 1934, the Red Army Department of Political Affairs issued a "on our military along the line of attention and Miao relations and strengthen the discipline inspection instructions," provides: "for a wide range of ethnic groups for all walks of life, do not fight Miao people, Miao people in the prestige of the long, mayor, in order to protect the local people's production, never to kill cattle, land of cattle should be distributed to the poor. "Instruct the troops" to strengthen discipline inspection, to overcome all violations of the masses from the masses of the action, to the soldiers in-depth propaganda of the party's national policy and strictly supervise the implementation. "In January 1935, the Red Army into Guizhou, for the multi-ethnic, complex features, the party solemnly issued" on the fight for ethnic minorities "Regardless of the Han nationality Miao, Buyi people; regardless of the number of ethnic groups, are equal; not allow the Han people to oppress the Miao, Buyi", "political, economic," and so on, Miao people, Dong people and the Han people have the same rights. " The national work and national policy of the Red Army during the period of Guizhou did not only eliminate the national estrangement and national prejudice, promoted the national unity, but also awakened the revolutionary consciousness of the ethnic groups in Guizhou, increased the ideological consciousness and enhanced the sense of identity of Marxism.

\subsection{Solve the Livelihood of the People, So that the Masses in the Recognition of the Belief in Marxism}

Marx pointed out: "Everything that people struggle for is related to their interests." Interests are the basis of all social relations, and the party can faithfully represent the fundamental interests of the people and gain the support and support of the masses. In the old society, because of the land owned by the landlords, the people of all ethnic groups in Guizhou suffered from the trample of the local gentry and the gentry, so that the "fight the land and the land" became the most urgent demands of the people of all ethnic groups. After the Red Army entered Guizhou, vigorously promote the party's land policy, such as "the implementation of the land revolution, knock down the local tyrants field, the implementation of the tiller has its field" "cancel all the Kuomintang exorbitant taxes, incineration field lease" Clothes, to the wealthy home to wear new clothes to "and 
so on. These slogans combine theoretical propaganda with the urgent demands of the masses, concise, accurate, agitated and persuasive. After the Red Army captured the city of Li Ping in Guizhou, immediately after the struggle to fight the land, confiscation of the landlord property, in Liping County, a lot of primary school entrance to the mass meeting, will be confiscated to the food, oil, clothing, cloth and daily appliances and then, one - the inventory is good, to the masses that "playing the rich and poor," the revolutionary truth, then the distribution. The distribution method has been agreed with the masses in advance, divided into three categories: the next is the poorest people, share the most things to food, clothing, money-based; B and other appliances or other debris-based; The poor peasant Hu Zou points lol a few pounds, the poor peasant Lu Lee's pork a few pounds, clothes, pieces of poor peasant Zhang Qing was three hundred pounds of millet, twine and soil cloth, the poor Luo Weiping a cotton, Wok a mouth, a box of meat and sugar a few pounds. They are nothing to share with the other work together, especially with the actual settlement of the people together to solve the people's livelihood, the United States, the United States and the United States, in the change of economic life and political status at the same time let them feel the party and the Red Army for their care, in order to enhance the theory of close and identity. Therefore, it is necessary to combine the propaganda of Marxism and solve the practical problems of the masses of the people, to bring them to see the benefits, they are willing to accept, agree with Marxism, in the recognition of further belief in Marxism.

\section{The Contemporary Enlightenment of Marxist Communication in the Guizhou Minority Areas during the Long March}

General Secretary Xi Jinping pointed out in the report of the 18th National Congress of the Communist Party of China that "the belief in Marxism, the belief in socialism and communism is the political soul of the Communists and the spiritual pillars of the Communists who have been subjected to any test." The heroic epic feat stems from the revolutionary ideals of heaven and the firm belief in Marxism. During the Long March period, the popularization of Marxism in the ethnic areas of Guizhou was remarkable, so that the party and the Red Army won the support of the minority and won the initiative of the revolution, and its contemporary value was rich.

\subsection{Adhere to the Party's Mass Line, according to the Needs of the Masses Need to Choose to Disseminate Content, Promote the Popular Process}

Xi Jinping pointed out: "Our party from the people, rooted people, serving the people, the party's foundation in the people, the power in the people. Lost people's support and support, the party's cause and work cannot talk." Party mass work, is the Chinese workers and peasants Red Army to obtain an important guarantee for the victory of the Long March. Marxist theory belongs to the "critical weapon", this weapon is only the masses to master, can really become a reform of society and promote the historical progress of the material strength. Therefore, promoting the popularization of Marxism is bound to mobilize the masses and rely on the masses, and the spread of Marxism must be based on the needs of the broad masses of the people. Marx believes that "once the idea of leaving the interests, it will make their own ugly", so the Red Army during the Long March has always stressed that publicity must be with the local people's actual interests closely. "Red Star" stressed that the propaganda along the people along the way, "must first of all from the vital interests of the masses began, and then gradually into the Soviet propaganda, must be the most popular language, great patience, close to the masses, to inspire them but our propaganda and agitation will not attract the interest and attention of the masses. "At present, the Chinese people opened a new long march period, will be in the second century to achieve the great rejuvenation of the Chinese nation in China dream. To achieve the Chinese dream, we must always adhere to the views of the masses, practice the mass line, and always adhere to all for the people. All rely on the people, in order to get the majority of people, including ethnic minorities, including the support, respect and support. Therefore, in the process of promoting the popularization of Marxism popularization, we should inspire the masses with the mass line of the party, gain in-depth understanding of the interests of the masses, the way of thinking, the habits and so on, and respect 
their subjective and pioneering spirit. To promote the masses to participate in the enthusiasm and innovation and vitality, so as to achieve and promote the popularization of Marxism, and ultimately the people united around the party, condensed into a strong Chinese strength, firmly take the road of Chinese characteristics.

\subsection{Implement the Party's National Policy, Creatively Develop Marxist National Theory in Practice and Reduce the Popularity of Resistance}

Guizhou is the Red Army Long March through the first ethnic minority living in more provinces, the party's national policy here in the initial practice and initial results. The Red Army, through sincere exchanges with the ethnic minorities along the way, in-depth understanding of the various nationalities of politics, economy, religion, culture, customs, etc., to correct the past in dealing with national issues on some of the deviation, the development of a more reasonable national policy, more in line with the reality of the minority, but also won their support. It can be said that the Red Army in Guizhou out of every step, are inseparable from the support of ethnic minorities, which was the implementation of the correct national policy has a great relationship, the support of the people of all ethnic groups to become a major guarantee for the victory of the Long March. The Long March period was the first time that the party's national policy was accepted for practice and began to mature. The national policy formulated by the Party during the Long March not only adhered to the general principles of Marxism-Leninism on national theory, but also combined with the concrete reality of ethnic minorities in China, creatively developed the Marxist theory of Marxism-Leninism, and put forward a set of More in line with Chinese national conditions of national policies, principles and measures to ensure that the Red Army's long march victory. During the period of the Red Army's long march in Guizhou, the national policy of Guizhou has been strongly supported and sincerely supported by the ethnic minorities. The successful practice of these policies has continued to improve the party's national policy today, do national work, promote economic and social development in ethnic areas and safeguard the motherland Unity and prosperity of the situation, adhere to national unity, against national division. Have a very important historical significance and reference.

\subsection{Innovate and Popular Publicity Path, Identify the Interests of Concern, Emotional Resonance, Enhance the Theoretical Affinity}

Mao Zedong said: "We say that Marxism is to live in the struggle of the masses, the actual role of the struggle of Marxism." Marxist theory of profound, different countries of different times the Communists are always based on the actual revolution and the needs of the building, Marxist focus, selective learning and dissemination. The Communist Party of China will be Marxism and the masses of life, mass struggle closely, not only verbally propaganda, but to identify the interests of the masses of concern and emotional resonance points. The Long March is a strategic shift, to get rid of the Kuomintang's besieged and seek its own development and growth, is the party and the Red Army is facing the largest and most important military and political tasks. Therefore, the popularization of Marxism in the Long March mainly focused on the military struggle as the center, focused on the concept of class struggle, launched along the masses against the landlord warlords, and actively support the party and the Red Army led the revolutionary war. Marxism can be accepted by people along the way, only through the spread of science can be achieved. From the perspective of communication, the information to reach the recipient must be achieved through a certain way. During the Long March, the Party and the Red Army created a variety of communication paths, mainly mass communication, organizational communication and interpersonal communication. Mass communication mainly relies on propaganda institutions, mass organizations and schools and other organizations to spread Marxism; interpersonal communication mainly through cultural activities such as cultural activities, such as the use of cultural activities such as newspapers and periodicals, Performance drama, singing songs, lectures and other forms, in the exchange of ideas on the basis of emotional understanding of positive interaction, mutual influence, deepen the recognition of Marxism. Regardless of the propagation path used, the theoretical propaganda cannot be too dominant to preach, must identify the interests of the people 
concerned about the point of interest and emotional resonance, in order to enhance the affinity and attractiveness.

\section{Acknowledgements}

Fund Project: 2017 Sichuan Agricultural University Social Science Research Project (2017ZT01)

\section{References}

[1] Xiao Hua: "Recapture the Red Army in the minority areas", "Chinese nation" in August 1983.

[2] Guizhou Province revolutionary historical relics investigation and collection office: "Qianshan red trace", Guizhou People's Publishing House, 1981, p. 220.

[3] Zhou Xigen: "Red Army Long March period of the party's national policy", Chengdu: Sichuan Nationalities Publishing House, 1985, p. 174.

[4] "Marx and Engels Complete Works (Volume 1)", People's Publishing House, 2011, p. 187.

[5] Hong Tao: "Long March period of the Red Army in Guizhou ethnic areas of the slogan and the party's propaganda strategy", Guizhou ethnic research, August 2016.

[6] "Red Army Long March after Guizhou ethnic minority areas investigation", Guizhou Provincial Institute of nationalities published, September 1965, page 4.

[7] Li Congjun, Zhao Cheng, Li Keyong: "facing the future examinations - General Secretary Xi Jinping Hebei Province to guide the party line of the practice of education activities," People's Daily, 2014-03-24.

[8] "The Complete Works of Marx and Engels" (Chinese Version 1, Volume 2), People's Publishing House, 1953, p. 103

[9] Lin Zhida: "History of the Communist Party of China propaganda", Sichuan People's Publishing House, 1990, p. 68.

[10] "Selected Works of Mao Zedong (Volume 3)", People's Publishing House, 1991, p. 858. 